\title{
Development and Implementation of Media Learning Digital Comic in Basic Competency of Harvesting Models for Online Learning APHP Student SMK Negeri 1 Sukaluyu Cianjur
}

\author{
Bonita Firdiana, Masriam Bukit*, Sri Handayani \\ Agroindustry Technology Education \\ Universitas Pendidikan Indonesia \\ Bandung, Indonesia \\ bonitafirdiana@student.upi.edu, *masriambukit@yahoo.com, srihandayani@upi.edu
}

\begin{abstract}
Learning activities using ordinary media like textbooks making the students disinterested to pay attention the material provided, especially for online learning. Therefore, digital comics were developed to be a solution that can be accessed anywhere, enjoyable to use, and make learning become more fun. The purposes of this research are to know the feasibility of digital comics as a learning medium and to find out student responses of online learning using digital comic media. Digital comic learning media was developed using the ADDIE (Analyze, Design, Development, Implementation, Evaluation) method and used in online learning in WhatsApp group, X APHP class, SMK Negeri 1 Sukaluyu, to find out students responses of digital comic. The results of the feasibility assessment of comic experts, material experts, and linguists got the category "very feasible" with consecutive percentages of $87.50 \%, 97.50 \%$, and $92.86 \%$. The feasibility of media experts obtained $79.17 \%$ with the category "feasible." The average percentage of eligibility of digital comics from student respondents was $88.17 \%$ with "very feasible" category. Based on the implementation of online learning and interviews, students are interested in using digital comics, but there are obstacles faced by students, like difficulties in accessing digital comics and limitations of internet.
\end{abstract}

Keywords—digital comic, online learning, student response

\section{INTRODUCTION}

Learning is a process of change that occurs in life to form an increase in behavior and knowledge. In the learning process in schools, several supporting devices are needed so that the process can run smoothly. The teacher is one of the important supporting tools in learning. The teacher provides material using learning tools or media to make it easier to deliver teaching materials.

In the learning process, student's success is determined by their ability to read because most of the knowledge is presented in written language so that students are required to do reading activities. However, learning in schools generally uses BSE (Electronic School Book) textbooks, Student
Worksheets (LKS), or PowerPoint presentations which have a weakness, namely students' disinterest in paying attention to the material provided and learning becomes boring [1]. The results of the research from Programme for International Student Assessment [2] also explain that Indonesia ranks 64 out of 72 countries for literacy in science, mathematics and reading. This proves that the motivation of students in Indonesia to read still needs to be improved. Based on observations during the implementation of the Education Unit Introduction Field Program (PPLSP) at SMKN (Public Vocational High School) 1 Sukaluyu Cianjur, students seemed less enthusiastic in paying attention to the teacher explaining the material with PowerPoint presentation media, some students looked sleepy in class and even fell asleep in class. Therefore, a media that attracts students' hearts is needed to increase motivation in learning, students' reading interest and increase students' understanding of the material provided.

Comics are a media that can be developed to increase student interest and motivation in expanding their knowledge about the material provided. Comics are reading materials that have a story line and images so the material is easy to remember. Comics can also be used as digital literacy media that can provide moral messages that motivate students to learn and can be accepted by the millennial generation. According to Daryanto in Widyastuti [3] one of the advantages of comics, by reading comics intensively, for example one comic for one month, is the same as reading a textbook in a year.

Comics are an example of a very popular visual narrative, combining the benefits of engaging metaphorical visualization and character-based narration so that comics have the potential to make scientific objects more understandable and attractive to the general public. In science-based learning, illustrations such as diagrams or other visual data play a very important role. Scientific visualizations or designed illustrations have been shown to improve knowledge acquisition skills and 
problem solving skills. In understanding a scientific visualization requires expertise to describe the information contained. Visual narratives as comics can help make deciphering information easier by using words and pictures and dividing information into panels that can facilitate a reading experience and highlight important information [4].

In addition, comics not only break down information into more digestible units but can also rearrange it into meaningful compositions. The content of each panel in the comic derives its meaning not only from the text or visual content, but from the trans-linear relationship with the surrounding panels and the composition of the page as a whole. In other words, comics can be read linearly, panel by panel, and also provide a non-linear explanation, which encourages readers to continually re-evaluate previous panels to clarify new information. Likewise, subjects such as science often require readers to make connections between different domains of knowledge. Comics are often seen as an easy and fun format, perfect for presenting complex information. In this regard, it will be interesting to explore the application of comic patterns to data visualization and other types of scientific visualization [5].

Based on research in Putri [6], regarding the use of comic media shows an effect of $27.04 \%$ on the increase in learning outcomes of 1st grade class in SMAN (Public Senior High School) 9 Pontianak on chemical compound nomenclature material. Then in Zurika [7] research, it shows that student learning outcomes have increased by $34.29 \%$ with the use of comic media through the Learning Starts With A Question method on the subject of trading company financial statements for students of SMK (Vocational High School) Pangeran Antasari Helvetia Medan. Therefore, comics are presented digitally can be used as learning media that help students understand the material easier, enjoyable to used and paperless. The purpose of this study was to determine the feasibility of digital comics as a learning media for basic competency of harvesting model in the Basic Handling of Agricultural Products Subjects and to determine student responses to online learning using digital comic media.

\section{MeTHODS}

In this study, two research methods were used. First, the method of developing digital comic learning media is using the ADDIE method (Analyze, Design, Development, Implementation, and Evaluation). Second, in online learning which is carried out through WhatsApp groups of X APHP $\left(1^{\text {st }}\right.$ grade student in Agribusiness Processing of Agricultural Products Major) SMKN 1 Sukaluyu with digital comic learning media that has been developed. The data from the implementation of digital comic media in online learning is in the form of descriptive-qualitative data.

\section{A. Population and Sample}

The population of digital comic media development (assessment of student respondents' eligibility for digital comic media) is the XI APHP students (2nd grade student in Agribusiness Processing of Agricultural Products Major) who are included in the WhatsApp class group, which is 54 person. The sampling technique for assessing the student respondents is purposive sampling with criteria of having a smartphone, WhatsApp account is still active, and willing to fill in the google form respondent assessment sheet on the WhatsApp group or on personal chat. From the results of purposive sampling, it was found that 21 students in XI APHP class responded and were willing to fill out the google form.

The population for the implementation of learning using digital comic media was was 54 person in X APHP class (1st grade class in Agribusiness Processing of Agricultural Products Major). Personal interviews were also conducted with students to find out their responses to digital comic learning media for material on basic competency of harvesting models in The Basic for Handling of Agricultural Products Subjects and responses to online learning using digital comic learning media. Interviews were conducted with students who responded to personal chat from researchers and were willing to be interviewed. The number of students interviewed consisted of 8 students X APHP 1 and 8 students X APHP 2. Interviews were conducted in chat messenger, sending voice notes, or by telephone.

\section{RESULTS AND DISCUSSION}

\section{A. Development of Digital Comic Learning Media}

The Development of digital comic learning media was using ADDIE method as follows:

1) Analysis: The first stage in this research is to analyze the needs of students. This needs analysis is carried out to determine the potential and problems that exist in the basic handling of agricultural products lesson. The analysis was based on observations made by researchers during PPLSP (Education Unit Introduction Field Program) activities and obtained as follows:

The X APHP students majoring have smartphones which are mostly used for communication through social media and playing games. Learning using a smartphone implemented when the teacher asks for group work and doing tasks (searching) only. There is no media that allows students to read material independently at home other than presentation files and module document files in the form of PDF (Portable Document Format). Students read the material through powerpoints or notes that the teacher has given. The learning media used in the classroom are powerpoints and BSE teksbooks only and makes students bored in class.

The needs analysis is not only seen from observations in PPLSP activities, but also seen from the current state of the world which is currently being hit by the Covid-19 pandemic outbreak, so students are required to implemented online learning at home. Based on these problems, a fun and 
accessible learning media to students is needed anywhere and anytime with a smartphone. Digital comic media can be a solution so that students can maximize the use of smartphones for learning at home in a more enjoyable manner.

2) Design: The design stage is a follow-up to the analysis stage. At this stage, making digital comics begins with making a story line or comic storyboarding according to the material in the Basic Competency of Harvesting Models, planning the comic format and website storyboarding, then continuing with making sketches of comics images on paperand making it digitally.

3) Development: The development stage is the realization stage of the design. The making of digital comics is carried out in accordance with the storyline and the designed image sketches. The sketch of the image is scanned so that the image on the paper media can be converted into digital form. The results of the sketch will be edited on the computer using the Graphic Tablet and the Medibang Paint Pro program (Figure 1 ), so that the shapes and lines of the image are more clearly visible.

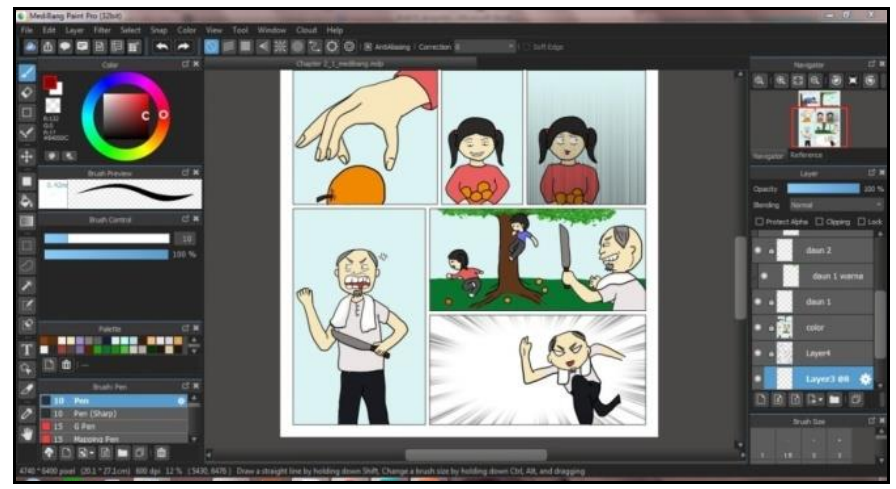

Fig. 1. The process of making digital comics using Medibang Paint Pro.

Comics are made vertical (one-shot comic) so that readers can easily read them in digital form by scrolling. Digital Comic Media can be opened through the website, it easier for students to access digital comic via the Google search engine by typing the URL link : https://bonitafirdiana.wixsite.com/edcomic.

The appearance of the website is made as attractive as possible by taking the agricultural products nuances (Figure 2 ), so students are interested in opening the website and browsing the website further.

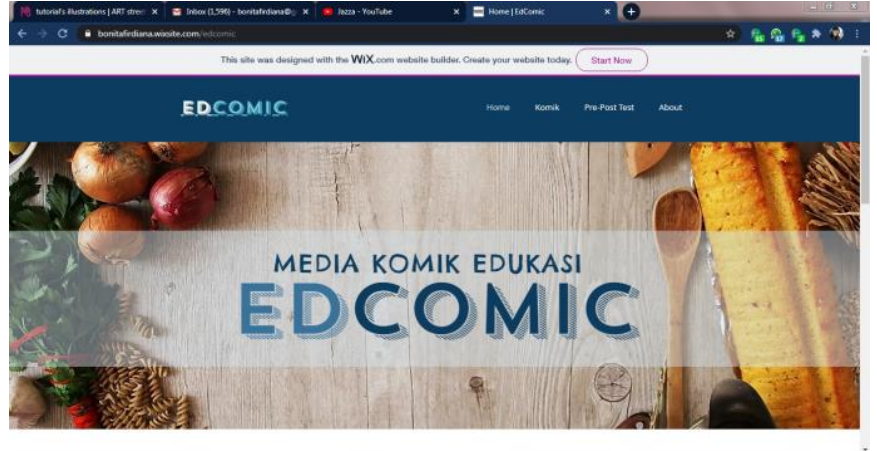

Fig. 2. The appearance of a digital comic website.

Digital comic media needs to be validated by experts to find out opinions and measure the feasibility of the media. Validation was doing by 4 experts i.e. comics expert, harvesting model materials expert, Indonesian linguist, and media expert.

Based on the results of the assessment of the comic experts, the percentage was $87.50 \%$ and it was in the "very feasible" category. "The results of the assessment from the material expert obtained a percentage of $97.50 \%$ with the category" very feasible." The assessment from linguist showed that the media digital comic "very feasible " with percentage of $92.86 \%$. The results of the media expert's assessment obtained a percentage of $79.17 \%$ with the criteria "feasible."

4) Implementation: In the implementation stage, it was carried out through from student respondents who had completed learning the harvesting model in Basic Handling of Agricultural Product, namely XI ( $2^{\text {nd }}$ grade) class, majoring in Agribusiness Processing of Agricultural Products. The overall average of the indicators provided is $88.17 \%$ with the category "very feasible." So it can be concluded that the students strongly agree with the development of digital comic learning media on the basic competencies of the harvesting model in the basic subject of handling agricultural products.

5) Evaluation: The evaluation stage is the stage to improve the resulti of development product. Improvements are made starting from the development stage based on criticism and suggestions from experts, as well as improvements from the implementation stage based on criticism and suggestions from students' responses. Based on criticism and suggestions from students, it was found that the digital comic media that had been developed still needed improvement. Suggestions and criticisms from students include the use of language / terms in learning that are still not understood by students such as trimming, grading, and conveyor belts. Writing the word size according to the students is too small, as well as the use of regional languages that are deemed unnecessary. 


\section{B. Online Learning Implementation Using Digital Comic Media}

Digital comics that have been developed are applied to online learning. Online learning is carried out through WhatsApp social media. It is used because it is an application for communication that is widely used by students. During online learning at home, students get material through social media such as WhatsApp. Online learning with digital comics is delivered through WhatsApp because it considers students to interact more and communicate through this application. WhatsApp is also easier to use by students who have limited cellular storage space or internet data. WhatsApp is a fairly lightweight application compared to downloading a video conference application.

During the learning process, the researcher provides a digital comic website link so that students can access digital comics that have been developed. Not only links of course is given, but the researchers also provided a voice message (voice note) to explain some of the materials and video explanations are contains a brief explanation of digital comics. Researchers also asked several questions for students to answer about the material and asked their responses to the digital comics that were developed.

In online learning, there are several obstacles that are felt by researchers and students. Researchers still feel the limitations of the WhatsApp application as a medium for delivering material with digital comics, namely: The ineffectiveness of explaining by typing messages directly, the limited video sending duration and teachers have to wait to get student responses, replies or student responses, it can be said that this online learning take a long time and it wastes time in lessons. The obstacles that students feel in online learning with digital comics are difficulty of access the digital comic through website link and cannot open the video explanation of digital comic that has been given due to the lack of internet data, poor internet signal, or insufficient cellphone storage space. Even so, The implementation of online learning on WhatsApp using digital comic media is quite good. There are students who respond to learning with digital comics and answer the questions asked by the teacher. Students also felt happy with the digital comics provided. Through online learning with digital comic media, researchers have not received many responses, suggestions, or criticisms regarding the digital comic learning media developed. Therefore, interviews with students are needed to find out the reasons why students are interested or not interested in digital comics as well as corrective responses for the development of comic learning media in the future.

The discussion of the results of the interview is divided into three main topics, namely the first is regarding digital comic learning media for harvesting model material in the basic handling of agricultural products, the second is about digital comic media in online learning, and the third is about online learning that students do. The following is a discussion of the results of the interview:
1) Digital comics learning media for harvesting model material in the basic handling of agricultural products: Based on the results of the interview, students felt happy using digital comic media and became more interested in learning the harvesting material. Students think that digital comic is a fun media because they contain pictures and stories that make easier to understand harvesting material. Feelings of pleasure and interest are indicators of interest, and digital comics can increase the interest in learning. According to Slameto in Slameto [8], students who feel happy while learning, have participation or involvement and attentiveness are signs of interest in learning. Therefore, it can be concluded that the digital comic media that have been developed are sufficient to provide students with interest in learning.

Digital comic media that have been developed, received good responses from students. Based on the results of the interview, some students provided suggestions or criticism. It can be used to improve comic learning media in the future. In the interview, there were students who gave suggestions that digital comics can be even more varied in the delivery of their material. Other suggestions given were improvements in terms of images and stories in digital comics. Learning media need to be developed to be more attractive and simpler to make it easier to use. Students also hope digital comic media with offline mode, and easily accessible digital comic website links.

2) Digital comic media in online learning: The benefits of digital comic learning media besides being fun, exciting and increasing student interest, can also provide flexibility to students. This is evidenced by students who can re-open the website link or video explanation given when they have sufficient internet data to open it. Even though students are late in taking online learning at the specified time, the material through comics can be re-opened. Digital comics are an example of e-learning that is flexible to use. According to Elyas [9] there are several benefits of using digital-based learning media, one of which is flexibility which allows students to open learning material anywhere that has access to the internet.

Access to digital comic learning media is fairly easy with the provision of a digital comic website link or digital comic explanation video, however some students have problems accessing the digital comic, which hinders the process of delivering material. The causes of constrained access to digital comics are insufficient internet data, poor internet signal or network, and limited hardware / smartphones owned by students. Such technical constraints can cause the delivery of digital comic media of harvesting material to be hampered.

3) Responses about online learning that students do: Based on the results of the interviews, some students admitted that they were not too happy about doing online learning. Online learning can be said to be more relaxed and more 
flexible, but students also think that online learning is not fun because it is difficult to interact or discuss with their peers, a feeling of reluctance to ask the teacher via online messages, questions about learning that are not answered by teachers due to closed messages with other chats in online learning groups. Online learning has advantages such as the speed of delivery of material and flexibility in terms of time, however technical constraints such as inadequate internet access can hinder the learning process online. This is in accordance with Yodha's statement [10] that an unstable internet network can interfere online learning. This difficulty also affects when students use digital comic media in online learning, with no internet access, the learning process with any media cannot run well.

Some students admitted that they were lazy to learn through online learning during covid-19 pandemic, the reasons given were such as the atmosphere when studying at home was different from at school. There are also those who cannot do online learning because they have to work and do other activities at home. According to Widhiartha [11], through online learning, students are expected to become active learner, the learning process depends on how the students learn themselves. With the existence of learning media such as e-learning or digital comics that have been developed, students who have high enthusiasm, interest or motivation will easily master the material provided, but it is the opposite for students who tend to be lazy.

\section{CONCLUSIONS}

Based on the results and discussion, the feasibility of digital comics in Basic Competencies of harvesting models in the basic handling of agricultural products based on the judgment of comic experts, material experts, linguists get the category "very feasible" and based on media experts obtained "feasible" category. The average percentage of the feasibility from students' responses obtained the category "very feasible." Therefore, it can be concluded that the Digital Comic learning media that has been developed are "very feasible" to be used. In online learning with digital comics, the students responded that digital comics can increase understanding of the harvesting material and the students feel happy learning with the comic, this indicates that students are interested in digital comic media that has been developed. The students also expressed their obstacle, namely that they had difficulty in accessing digital comics due to lack of internet data, so they could open media when they already had internet data.

\section{REFERENCES}

[1] A.N. Wahyuningsih, "Development of Comic Comic Media with Neura System Materials for Learning Using the PQ4R Strategy". Journal of Innovative Science Education, 1(1), pp 19-27. 2012

[2] Programme for International Student Assessment, Organisation for Economic Co-Operation and Development. 2015.

[3] P.D. Widyastuti, "An Instructional Media using Comics on the Systems of Linear Equation”. Journal of Physics. 2017.

[4] M. Farinella, "The Potential of Comics in Science Communication". Journal of Science and Communication, 17(1), pp 1-17. 2018.

[5] B. Bach and N.H. Riche, "The Emerging Genre of Data Comics." IEEE Computer Graphics and Applications, 37(3). 2017.

[6] E. Putri, E. Enawaty, and I. Lestari, "The Influence of Using Comic Media on Students' Learning Outcomes in Chemical Compound Nomenclature". Chemistry Education Study Program FKIP Untan, pp 112. 2013.

[7] H. Zurika and R. Hasanah, The use of comic media through the Learning Starts With a Question method in improving student learning outcomes. The Progressive and Fun Education Seminar, pp 589-593. n.d.

[8] Slameto, Learning and the Factors Affecting It.Jakarta: Rineka Cipta. 2010

[9] A.H. Elyas, "The Use of E-Learning Learning Models in Improving the Quality of Learning”. Warta Journal. 2018.

[10] S.A. Yodha, "Student Perceptions of the Implementation of E-Learning in the Information System Management Course for Students of the Department of Educational Technology, State University of Malang". Journal of Educational Technology Studies. 2(3), pp 181-187. 2019

[11] P.A. Widhiartha, "The use of E-Learning as an alternative to face-toface training for non-formal educators and education personnel". Scientific journals VISI PTK-PNF. 4(2). pp 189-196. 2009. 